\title{
FEATURE The effects of 2011 Ohio and Mississippi river valley flooding on Cairo, Illinois, area
}

\author{
Kenneth R. Olson and Lois Wright Morton
}

n April 2011, the Ohio River began flooding farmland and cities from Pennsylvania to Illinois that were not protected by levees. The US Army Corps of Engineers (USACE) had realized as early as March that the torrential rains and heavy snow melt across the Upper Midwest were setting up the Mississippi River Basin for an epic flood year (USACE 2011). By late April, lakes and reservoirs along the Wabash and Ohio rivers were filled to capacity and cities without levees, such as Metropolis, Illinois, had lower sections covered by floodwaters. Cairo, Illinois, and many of the cities on the lower Mississippi River were protected by levees.

The levee is a massive earth works designed to contain floodwater. It has a flat crown at least $2.4 \mathrm{~m}(8 \mathrm{ft})$ wide with 3:1 sloped sides (a levee $9.1 \mathrm{~m} \mathrm{[30}$ $\mathrm{ft}]$ high would be at least $57.3 \mathrm{~m} \mathrm{[188 \textrm {ft } ]}$ wide, including $2.4 \mathrm{~m} \mathrm{[8} \mathrm{ft}]$ wide crown plus two sides, each $27.4 \mathrm{~m}$ [90 ft] wide). The height of the levee changes the force of the river; a levee as high as a three- or four-story building can explode with the same power and suddenness of a dam bursting. The greatest danger to levee failure is constant water pressure against the levee. The weight of the river pushes water underneath the levee, creating boils and undermining the strength of the levee and its capacity to hold water. By the end of April, the floodwaters on the levee and seawall at Cairo, Illinois, had reached 18.6 $\mathrm{m}(61 \mathrm{ft})$ and were rising. Floodwaters were starting to put significant pressure on the Cairo seawall and levee system with some seepage or sand boils.

The USACE decision to blow up Birds Point levee on the Mississippi River and flood agricultural lands in the New Madrid Floodway, Missouri, on May 2,

Kenneth R. Olson is professor of soil science in the College of Agricultural, Consumer, and Environmental Sciences, University of Illinois, Urbana, Illinois. Lois Wright Morton is professor of sociology in the College of Agriculture and Life Sciences, lowa State University, Ames, lowa.
2011, to protect the city of Cairo, Illinois (figure 1), was a calculated risk built on a growing body of river science and prior flooding experiences. The decision was a

\section{Figure 1}

Map of Cairo, Illinois, and the Ohio and Mississippi rivers confluence and Mississippi River from Cairo, Illinois, to Birds Point, Missouri.

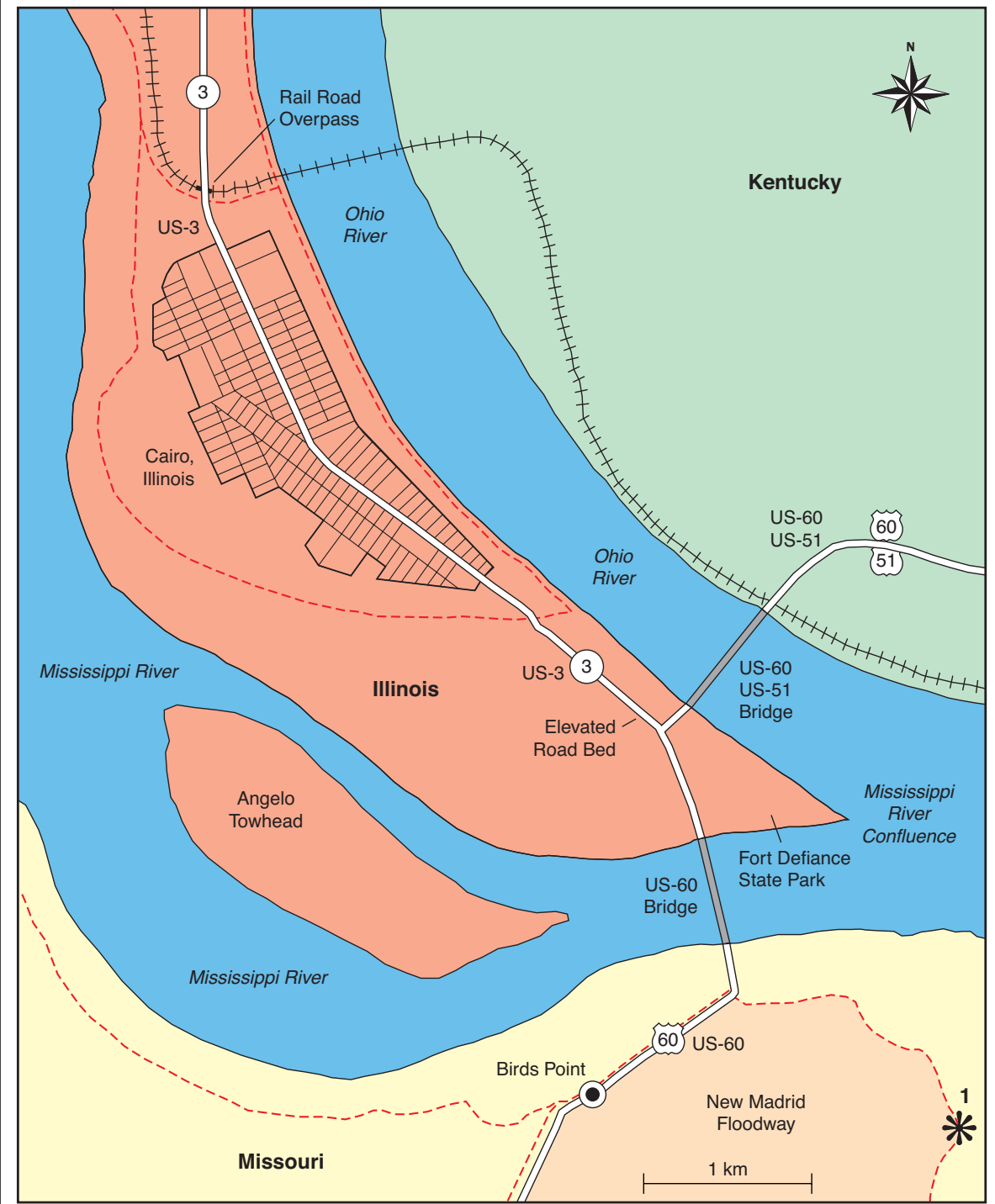

\section{Legend}

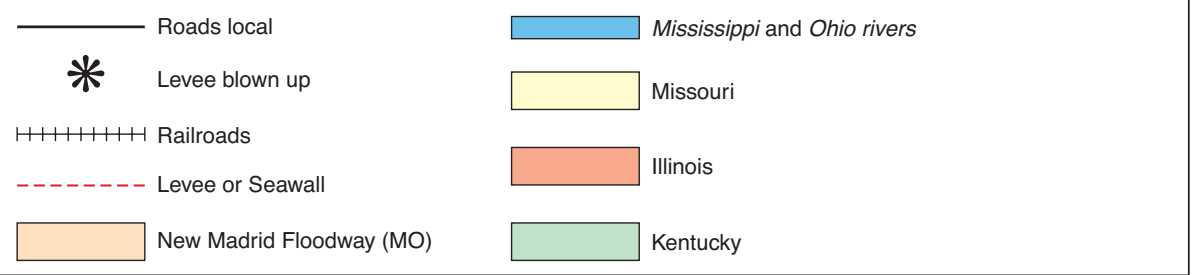

difficult and complex engineering problem with significant social and political trade-offs between loss of human lives and loss of properties in urban and rural areas. 


\section{THE CONFLUENCE OF THE OHIO AND MISSISSIPPI RIVERS AT CAIRO}

Cairo, Illinois, situated at 93 to $96 \mathrm{~m} \mathrm{(305}$ to $315 \mathrm{ft}$ ) above sea level, was built on Tice silty clay loam, Gorham silty clay loam, and Riley silty clay loam soils (Parks and Fehrenbacher 1968). The city is located at the confluence of the Ohio and Mississippi rivers and marks the beginning of the lower Mississippi River (figure 1). Because of Cairo's vulnerability to flooding from both rivers, the USACE has developed and implemented a variety of strategies to protect Cairo, a town of 2,900 people and 400 buildings, as well as other Ohio River and Mississippi River cities, from floodwaters. After the Great Flood of 1927 (Barry 1997), the USACE created the current Cairo seawall and levee system (figure 2) on the Ohio and Mississippi rivers. This seawall and levee system was sufficient to handle all previous flooding events until spring of 2011, when greater than average rains and snowmelt produced one of the most powerful floods in the river's history and threatened to top and breach the flood control system (USACE 2011).

The USACE anticipated that a 500year flood in this area would require the diversion of large quantities of flood waters through a floodway and into a temporary storage basin. Therefore, they developed the New Madrid Floodway project in Missouri, south of Cairo (figure 1). This area of land originally was part of a natural levee system created by the river overflowing its banks. A natural levee deposits the heaviest sediment first, thus building up the land closest to the river. These natural levees extend about 1 to $2 \mathrm{~km}$ (0.6 to 1.2 mi) from the riverbank and are adjacent to bottomlands, which are farther away and are lower marsh and swamplands. The New Madrid Floodway natural levees were fortified and heightened following the draining and ditching of marsh lands to create fertile agricultural lands (Olson et al. 2011). The New Madrid Floodway covers 53,824 ha $(133,000 \mathrm{ac})$ surrounded by levees and is capable of holding 3 to $3.6 \mathrm{~m} \mathrm{(10} \mathrm{to} 12 \mathrm{ft}$ ) of water or capable of temporarily holding 164,198 to 197,037 ha $m(1,300,000$ to $1,596,000 \mathrm{ac} f \mathrm{ft})$ of floodwater.
The Fort Defiance State Park (figure 3 ) is located just south of Cairo, Illinois, between the southernmost point of the Cairo levee and seawall system and the confluence of the Ohio and Mississippi rivers (figure 1). The park is the lowest point in the state of Illinois, with an elevation of 85

\section{Figure 2}

The Cairo seawall is on the Ohio River side at the bend where an earthen levee would be difficult to maintain. Factory worker vehicles are parked next to the seawall on May 20, 2011.

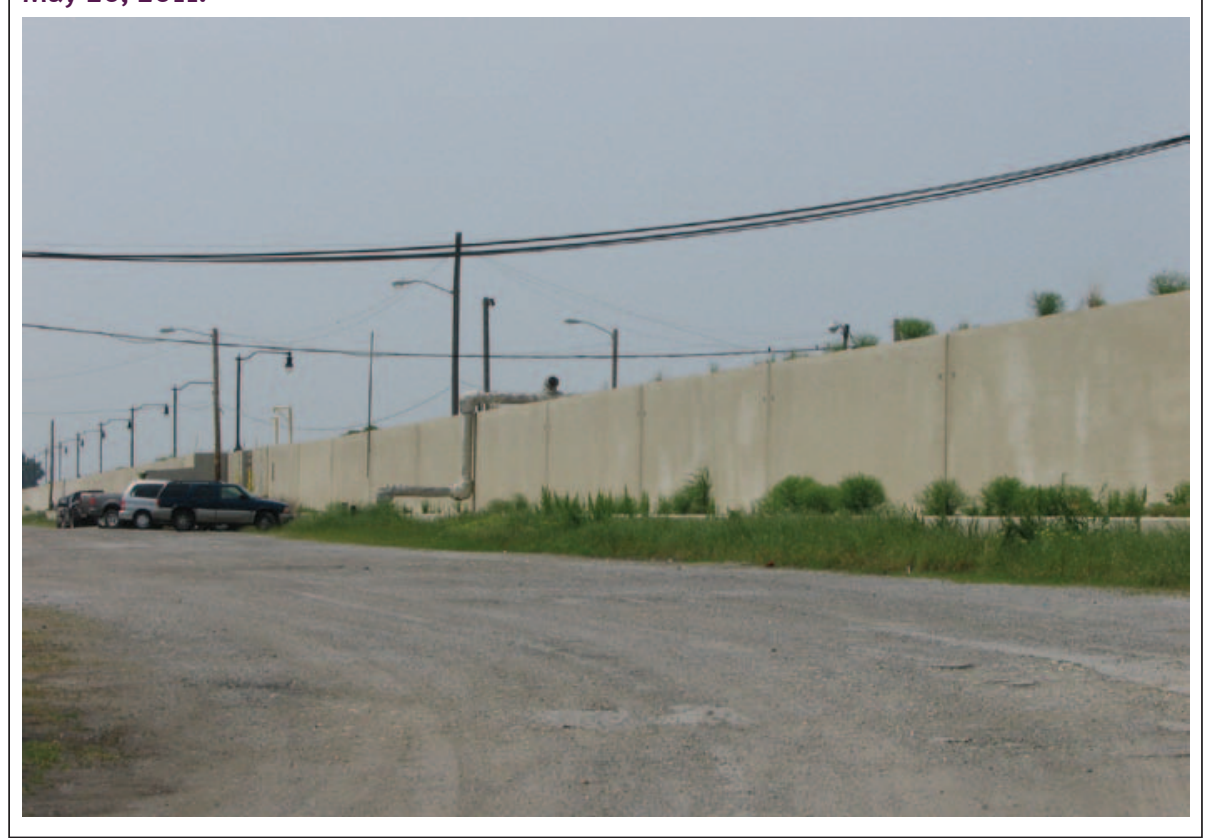

\section{Figure 3}

The Fort Defiance State Park trees are under water at the southernmost point of Illinois. The park is located south of Cairo levees and seawall and at the confluence of the Ohio (on the background) and Mississippi (on the foreground) rivers.

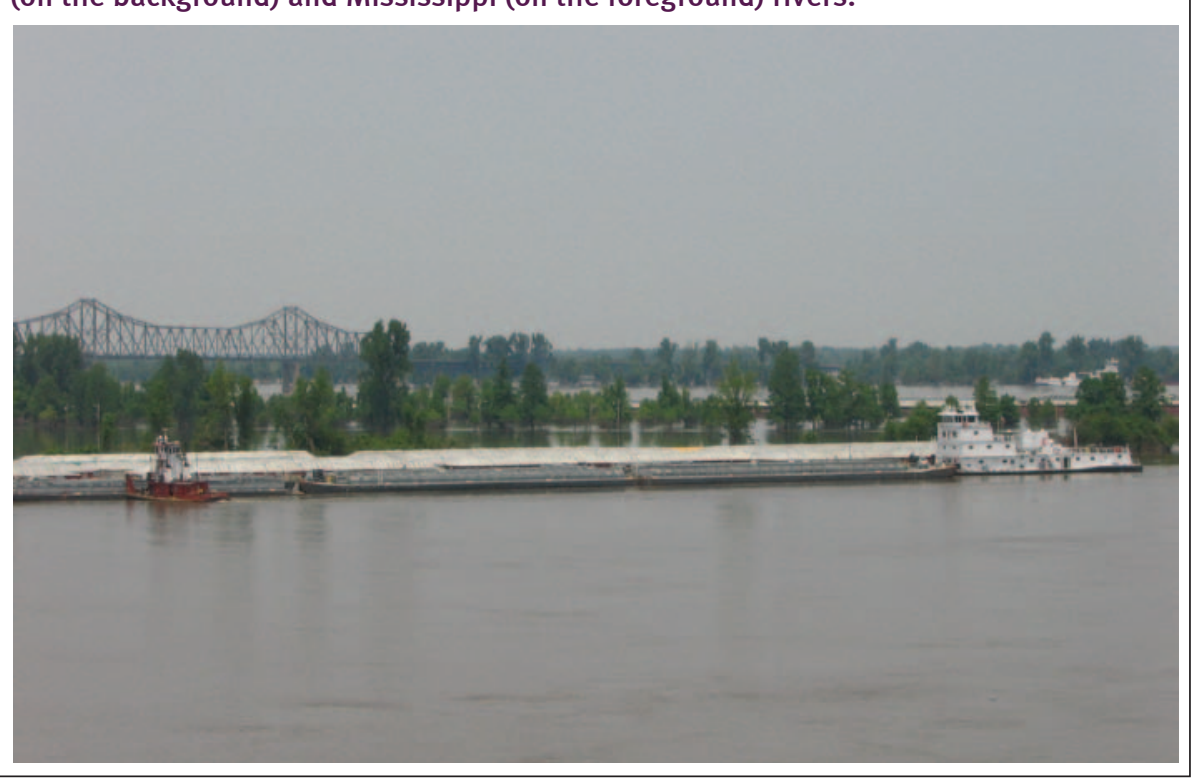


located west of the park and between the Mississippi River and the levee was also under water when the Mississippi River was above flood stage (Olson 2009).

The city of Cairo is only 518 ha $(1,280$ ac) in size, and, if the levee system were to fail, it is estimated that more than 6.1 $\mathrm{m}$ (20 ft) depth of water would flow in rapidly and cover the city with 2,962 ha $\mathrm{m}$ $(24,000 \mathrm{ac} \mathrm{ft})$ of floodwater. The northern boundary of Cairo is two adjacent raised railroad beds (figure 4) that are $4.6 \mathrm{~m}$ (15 $\mathrm{ft}$ ) and $12.2 \mathrm{~m} \mathrm{(40} \mathrm{ft)} \mathrm{above} \mathrm{Illinois} \mathrm{Route}$ 3 which passes underneath and through a tunnel. Between the raised railroad beds is a huge metal gate (figure 4), which can be lowered to block floodwaters from passing into Cairo from the north if the Cache River levee was to fail or be topped. During flood events, the entire city can be evacuated and sealed off from the floodwaters. If a levee or seawall system north of Cairo and on the Mississippi, Ohio, or Cache rivers failed, it would cause the flooding of Future City, Illinois, and the surrounding 809 ha $(2,000 \mathrm{ac})$ of agricultural lands and cause the Cairo floodgate to be closed. The Future City area includes 1,214 ha (3,000 acres) of protected land (Tice silty clay loam, Riley silty clay loam, Darwin silty clay loam, and Cape and Karnak silty clay loam) (Parks and Fehrenbacher 1968) north of Cairo and south of Cache River levee. The Future City area has the capacity to provide an additional 1,214 ha (3,000 ac) of unintended floodwater storage if the Cache River levee break occurred and an additional 3,804 to 5,556 ha $\mathrm{m}(30,000$ to $45,000 \mathrm{ac} \mathrm{ft}$ ) of floodwater storage. This area, which is at a slightly higher elevation, could store water to a 3 to $4.6 \mathrm{~m}$ (10 to 15 $\mathrm{ft}$ ) depth depending on location and also includes levee-protected Illinois farmland (Olson et al. 2011).

If a flood event were to occur, a hundred or more buildings in the Future City and Urbandale, Illinois, areas would be damaged, and the local population would have to be evacuated to prevent loss of life. The breaching of Cairo or Future City area levees or topping by floodwater above the $19.5 \mathrm{~m}(64 \mathrm{ft})$ maximum protection level, the 6,766 to 8,518 ha $\mathrm{m}(54,000$ to 69,000 ac ft) would do little to drop record flooding levels on the Ohio River (probably a

\section{Figure 4}

The raised railroad bed serves as the northern boundary of Cairo, Illinois, and provides an entry to the levee enclosed city for IL Route 3 traffic. Flood gates on this entry could seal the city behind embankments and seawall.

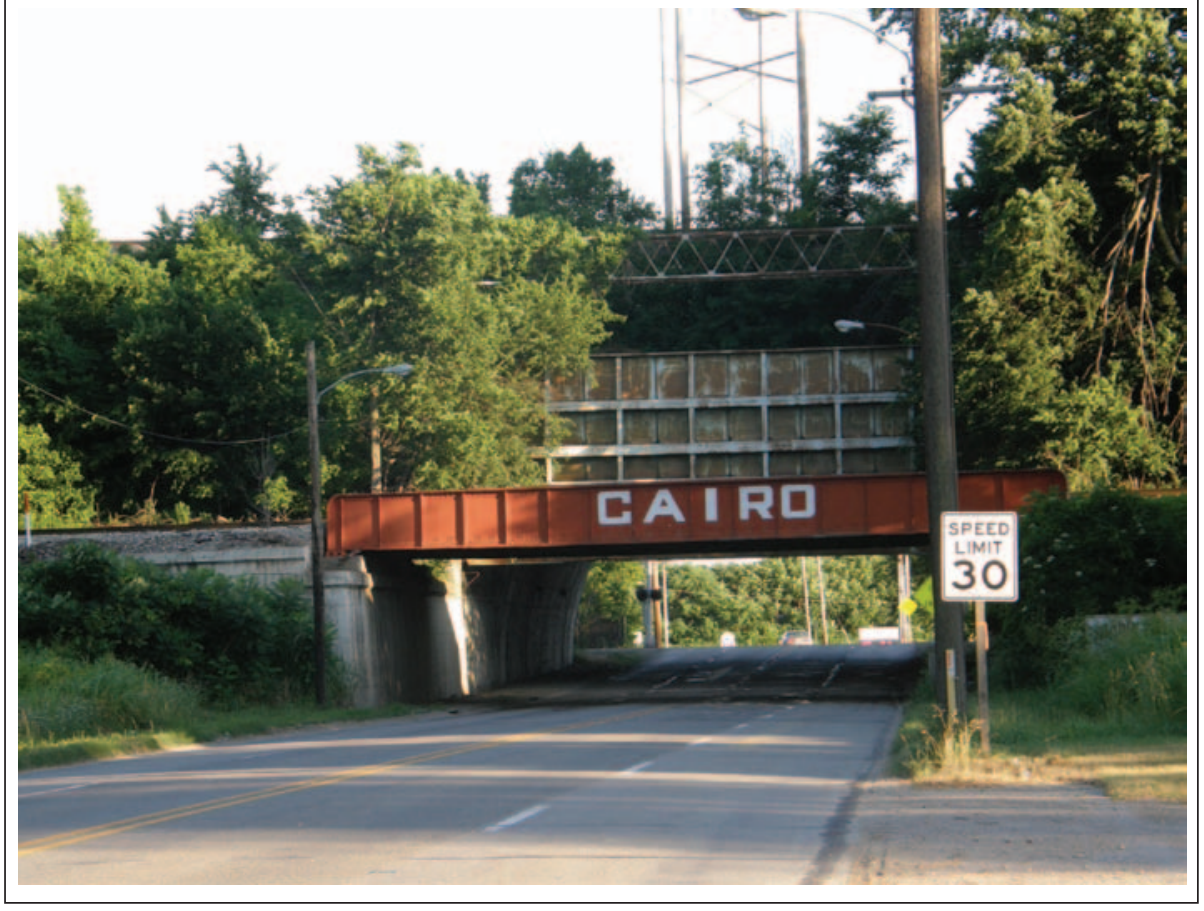

few centimeters [several inches]) and have even less effect in the Lower Mississippi River between Cairo, Illinois, and New Orleans, Louisiana. Cairo and Future City levee or seawall breaks and $4.6 \mathrm{~m}$ (15 ft) depth of rushing floodwater could have resulted in significant loss of life and severe damage to more than 600 buildings in the cities of Cairo, Future City, and Urbandale, Illinois. The 1927 Mississippi Flood map of overflowed areas (Barry 1997) clearly shows that both the Cairo and Future City areas were flooded and would have again if the seawall and levee system had failed.

\section{BLOWING THE FUSE PLUG AT BIRDS POINT, MISSOURI}

Mayor Judson Childs ordered an evacuation of Cairo, effective Sunday, May 1, 2011. Many of the evacuees were moved to Shawnee Community College as the danger of floodwaters topping the seawall or breaching escalated. On May 2, 2011, at 9:00 pm, Major General Michael Walsh ordered the Birds Point fuse plug levee (figure 5) to be blown up. About 240 t (265 tn) of dynamite was put into $335 \mathrm{~m}(1,100 \mathrm{ft})$ of pipe within the fuse plug levee, and the first sequence of blasts exploded with a force of 3 on Richter scale. The Birds Point fuse plug levee from Tom Bird Blue Lake to $3 \mathrm{~km}$ (2 mi) to the south (figure 1) was opened in six places by this explosion, and the subsequent force of the rushing floodwater from the Mississippi River removed the adjacent sections of the degraded levee (Olson and Morton 2012). The USACE estimated that nearly one-fourth of the entire flow of the Mississippi River entered the New Madrid Floodway at the rate of $11,213 \mathrm{~m}^{3} \mathrm{~s}^{-1}$ $\left(396,000 \mathrm{ft}^{3} \mathrm{sec}^{-1}\right)$. The diversion of the Mississippi River floodwater reduced the Cairo levee water level from $18.8 \mathrm{~m}$ (61.7 $\mathrm{ft})$ to $18 \mathrm{~m}(59 \mathrm{ft})$ within 48 hours. The city of Cairo, Illinois, was spared from a natural seawall or levee breach or topping. Most residents returned by May 11, 2011, but were subjected to a nightly curfew. By then, the peak flow had dropped about 1.8 $\mathrm{m}$ (6 ft), and by May 20, 2011, life in Cairo was starting to return to normal and business activity picked up.

After the deliberate breaching of the Birds Point levee and opening of the New Madrid Floodway, water levels dropped

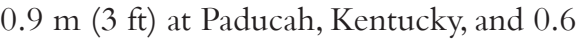
$\mathrm{m}(2 \mathrm{ft})$ at Cape Girardeau, Missouri. The 
US 51 bridge over the Ohio River from Illinois to Kentucky (figure 1) was opened once the Ohio River floodwaters were no longer passing over the US 51 highway. The Mississippi River was at $14 \mathrm{~m}$ (46 ft) on May 20,2011, and the road and bridge would normally remain closed until the Mississippi River dropped to $13.1 \mathrm{~m}$ (43 ft), which occurred by mid-June of 2011. However, the US 60 bridge over Mississippi River, which connects Cairo, Illinois, and Birds Point, Missouri (figure 1), was still closed on October 22, 2011, and will apparently remain closed until required bridge repairs are completed. The local Missouri and Illinois residents and any through traffic will continue to travel an additional $27 \mathrm{~km}(17 \mathrm{mi})$ for some time to get between Birds Point, Missouri, and Cairo, Illinois.

The Illinois agricultural land inside the Cairo seawall and levee system was protected from flooding and there was no crop loss or soil damage. The Illinois cropland outside the levee was flooded before the 2011 crop was planted, and the water dropped sufficiently by June 10 , 2011 , to permit the planting of soybeans (figure 6). The impacts of the induced breach of the Birds Point levee on 53,824 ha $(133,000 \mathrm{ac})$ of Missouri farmland in the Floodway resulted in the loss of 2011 crops and damage to future soil productivity. In the New Madrid Floodway, the strong current and sweep of water through the Birds Point breach created deep gullies, displaced tons of soil, and damaged irrigation equipment, farms, and home buildings (Olson and Morton 2012).

\section{KENTUCKY BOTTOMLANDS}

The record $18.8 \mathrm{~m}(61.7 \mathrm{ft})$ peak on the Ohio River at Cairo flood gauge resulted in thousands of hectares (thousands of acres) of unleveed Kentucky bottomlands being flooded. The Ohio River, which normally is $1 \mathrm{~km}$ ( $0.6 \mathrm{mi})$ wide, was almost $5 \mathrm{~km}$ (3 mi) wide. All unprotected bottomlands with an elevation of less than $101 \mathrm{~m}$ (332 ft) above sea level were flooded. These bottomlands are riparian forests-transition ecosystems between the river and uplands-which have fertile, fine textured clay or loam soils that are enriched by nutrients and sediments

\section{Figure 5}

The Birds Point levee was the site of the first explosion and is visible with remnants of the fuse plug levee and the crater lake extending into the adjacent agricultural lands that are still under floodwaters.

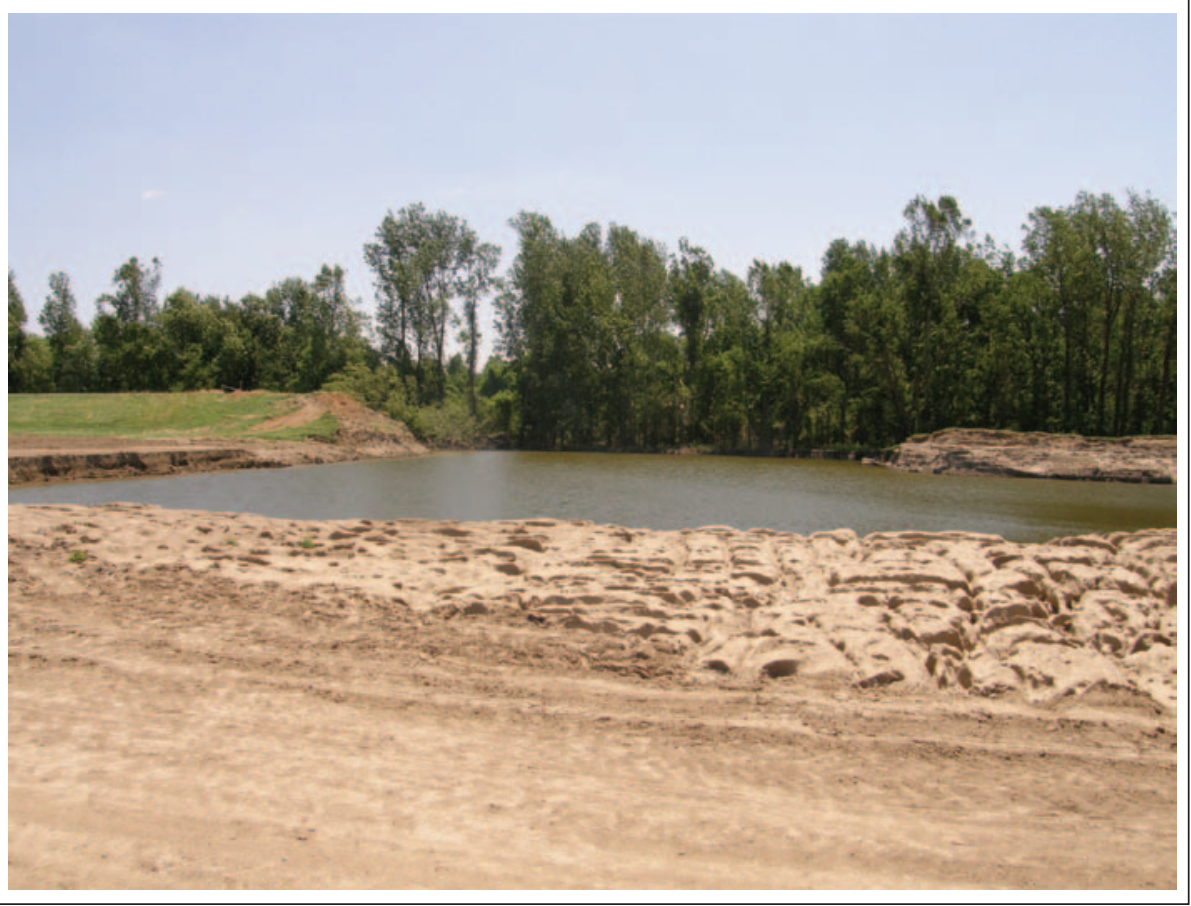

\section{Figure 6}

Fort Defiance State Park and adjacent Illinois agricultural land after Ohio River dropped and planted to soybeans by June 10, 2011.

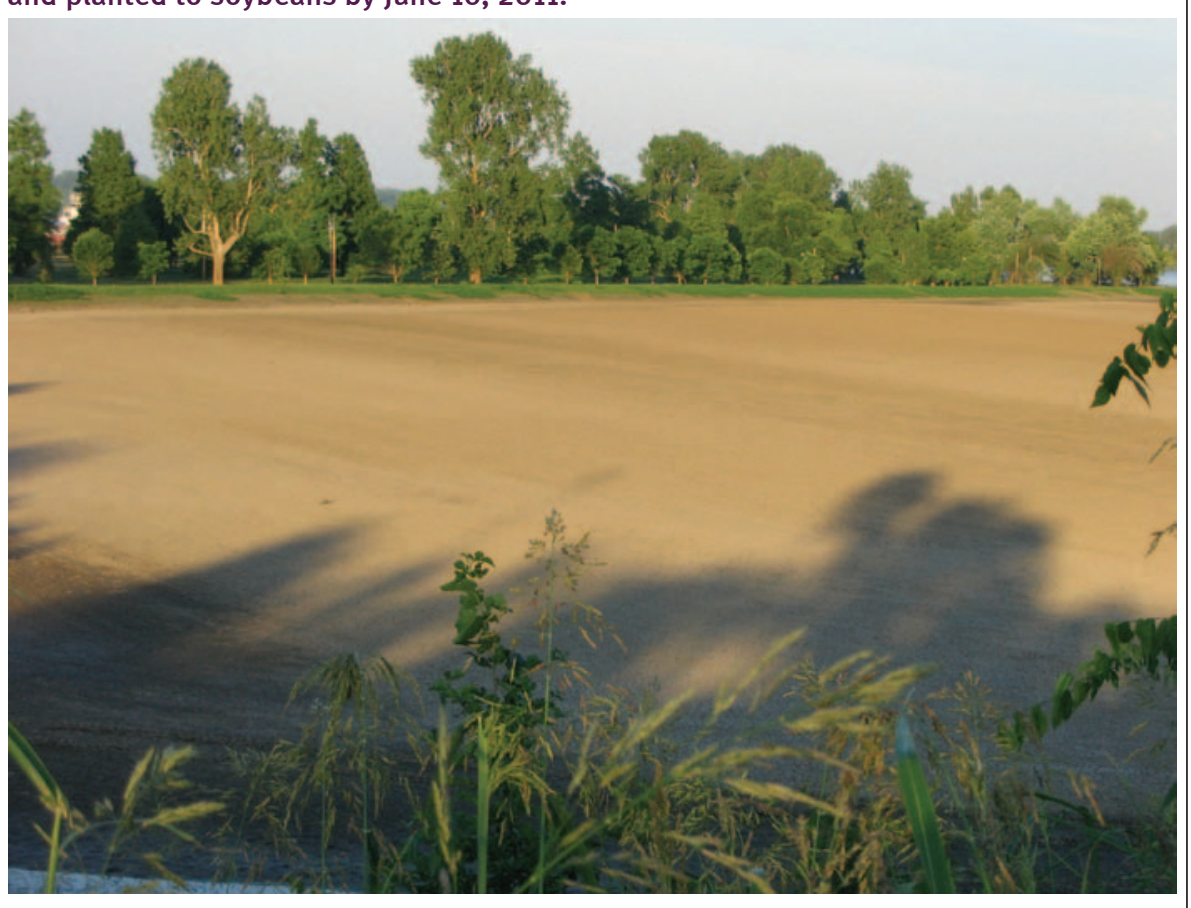

deposited during floods (Anderson and Samargo 2007). Bottomlands that experience periodic flooding have hydrophytic plants along with the hardwood forests, which provide habitat for resident and migratory birds and waterfowl, including shorebirds, owls, woodpeckers, wild turkey, songbirds, woodcocks, and a variety 
of duck species. In places where bottomland hardwood forests were clear-cut, silver maples, cottonwoods, and box elders have become established (Patterson 1996). The species of the alluvial river bottomland are well adapted to periodic flood cycles, which can last from several days to a month or more (Anderson and Samargo 2007). The impact of the 2011 flood duration (two to four weeks) on these wetlands, wildlife habitat, and woodlands, as well as on reproduction timing on nesting and fledging of bird populations, has not been assessed; however, this ecosystem is well suited for periodic inundation from heavy rainfall and river flooding. The Kentucky bottomlands provided additional water storage capacity during flooding, and the wet soils helped filter pollutants, recharge the water table, and capture sediment before it reached the main flow of the river (Anderson and Samargo 2007).

The raised railroad and highway (US 60) beds on the Kentucky bottomlands, which connect Cairo, Illinois, via elevated highway and railroad bridges across the Ohio River, to Wickliffe, Kentucky, were also flooded. The floodwaters covered $8 \mathrm{~km}$ (5 mi) of US 60 and the railroad bed for approximately two weeks in May before opening to the public and commercial use. Only a thin silt coating was visible on the road, with little damage to these road and railroad beds. Much of the Ohio River barge traffic was also stopped, with barges tied up on both sides of the river. Since there were no levees across from Cairo on the Kentucky side of the Ohio River, the bottomlands were not developed for urban uses and the floodplain was used to temporarily store the floodwaters. There were very few building structures on the Kentucky bottomlands and only limited agricultural use. Most of the unprotected Kentucky bottomlands had drained by May having served several multifunctional uses: floodwater storage, nutrient cycling, anaerobic conditions that slow down the decay of vegetative matter (carbon storage), and wetland habitat which supports a diversity of wildlife.

\section{CONCLUSION}

The purposeful opening of the New Madrid Floodway in May 2011 reduced the flooding and immense pressure caused by the rain-swollen, fast-moving Ohio and Mississippi rivers on towns like Metropolis, Illinois, Paducah, Kentucky, and Cape Girardeau, Missouri, as well as reduced the pressure on the seawall and levee system at Cairo, Illinois. The peak flow and flood levels at most levees on the lower Mississippi River and along the way to the Gulf of Mexico were lowered by $1 \mathrm{~m}$ (3.3 $\mathrm{ft})$. None of the Lower Mississippi River levees broke, but the historic floodwater levels on the Mississippi River as a result of flooding still required the opening of the Morganza flood gates and the rerouting of floodwater through the Atchafalaya River Valley, which is west of Baton Rouge, Louisiana, and a shorter route for floodwaters to enter the Gulf of Mexico. The impact of this floodgate opening on wetlands, agricultural land, and urban areas is the subject of other investigations.

Although most of the Mississippi Alluvial Valley was once covered by bottomland hardwood forests, most of the hydrology of these lands has been significantly altered with levees and cleared for urban development and agriculture. However, there were no levees across from Cairo on the Kentucky side of the Ohio River, and thus there were no levees to fail under the pressure of the floodwater. Consequently, these undeveloped bottomlands and the floodplain experienced minimal land degradation despite temporarily storing a portion of the floodwaters which they gradually released as the inflowing water pressure subsided. The Kentucky bottomlands, although not sufficient as a single flood control measure, were an important source of water storage during the 2011 flooding and provided valuable ecosystem services. The extensive loss of Mississippi River bottomlands to agriculture and urban development has limited the natural capacity of alluvial bottomlands to manage flooding in main river channels and reduce water pressure under extreme rain and snow melt events. Without natural wetland buffers, such as the bottomlands, floodwater will push against concrete and levees, increasing the height of the river channel, and cause the water to flow faster, intensifying pressures on flood control structures.
It appears that the USACE induced breach of the Birds Point, Missouri, levee and the passing of floodwaters through the New Madrid Floodway dropped the flood level at Cairo by $0.8 \mathrm{~m}(2.7 \mathrm{ft})$ in 48 hours, which reduced the water pressures on the seawall and levee system. The flood levels dropped $0.9 \mathrm{~m}(3 \mathrm{ft}$ )

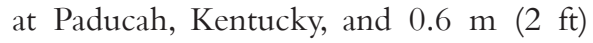
at Cape Girardeau, Missouri, within 48 hours. There was no loss of life or property in Cairo, Future City, or Urbandale, Illinois, since the levee and seawall system held back the record high floodwaters of the Ohio and Mississippi rivers for many weeks.

\section{REFERENCES}

Anderson, J., and E. Samargo. 2007. Bottomland Hardwoods. Morgantown, WV: West Virginia University, Division of Forestry and Natural Resources. http://forestandrange.org/new_wetlands/index.htm.

Barry, J.M. 1997. Rising Tide: The Great Mississippi Flood of 1927 and How it Changed America. New York: Simon \& Schuster.

Olson, K.R. 2009. Impacts of 2008 flooding on agricultural lands in Illinois, Missouri, and Indiana. Journal of Soil and Water Conservation 64(6):167A-171A. doi:10.2489/jswc.64.6.167A.

Olson, K.R., and L.W. Morton. 2012. The Impacts of 2011 Induced Levee breaches on agricultural lands of Mississippi River Valley. Journal of Soil and Water Conservation 67(1):5A-10A. doi:10.2489/jswc.67.1.5A.

Olson, K.R., M. Reed, and L.W. Morton. 2011. Multifunctional Mississippi River leveed bottomlands and settling basins: Sny Island Levee Drainage District. JSWC 66(4):104A-110A. doi:10.2489/jswc.66.4.104A.

Parks, W.D., and J.B. Fehrenbacher. 1968. Soil Survey of Pulaski and Alexander counties, Illinois. Washington, DC: USDA Natural Resource Conservation Service.

Patterson, R. 1996. Returning diversity-and nutsto bottomland forests. Tree planting projects in the Mississippi River Bottomlands. American Forests (Spring).

USACE (US Army Corps of Engineers). 2011. Great Flood of '11. Our Mississippi. Rock Island, IL: US Army Corps of Engineers. http://www.mvs. usace.army.mil/Our\%20Mississippi/ourmississippi_su11_lowres.pdf. 